\title{
Future sea-level rise due to projected ocean warming beneath the Filchner Ronne Ice Shelf: A coupled model study
}

\author{
Malte Thoma*, Jürgen Determann, Klaus Grosfeld, Sebastian Goeller, Hartmut H. Hellmer \\ Alfred Wegener Institute, Helmholtz Centre for Polar and Marine Research, Bussestrasse 24, 27570 Bremerhaven, Germany
}

\section{A R T I C L E I N F O}

\section{Article history:}

Received 23 December 2014

Received in revised form 2 September 2015

Accepted 7 September 2015

Available online xxxx

Editor: J. Lynch-Stieglitz

\section{Keywords:}

modelling ice-ocean interaction

Filchner-Ronne Ice Shelf

impact of climate/ocean warming

sea level rise

\begin{abstract}
A B S T R A C T
A general ocean circulation model is coupled with a 3D-thermodynamical ice-sheet/shelf model to simulate the response of the Filchner-Ronne Ice Shelf (FRIS, Antarctica) and coastal parts of its catchment basin to a postulated inflow of Warm Deep Water into the ice-shelf cavity on a 1000-yr timescale. Prescribed ocean warming (based on climate projections) enters the ice-shelf cavity in the up to $1500 \mathrm{~m}$ deep Filchner Trough and penetrates deep into the sub-ice cavity. Increasing basal melt rates induce geometry changes of the cavity, which in turn have an impact on the ocean circulation and therefore the modelled melt rates. Highest melt rates of about $20 \mathrm{~m} \mathrm{yr}^{-1}$ follow the (up to $180 \mathrm{~km}$ ) retreating grounding line. Basal mass loss reaches about $250 \mathrm{~km}^{3} \mathrm{yr}^{-1}$, doubling the present-day value. The most vulnerable areas below the FRIS are the Bailey Ice Stream and the area between the Institute and Moeller Ice Streams, where the increased melting accounts for about $80 \mathrm{~km}$ of the modelled grounding line retreat on the backward sloping bedrock. The potential additional contribution to the eustatic sea level rise due to the grounded-ice loss, simulated in an ensemble approach against a transient control experiment, is about $0.05 \mathrm{~mm} \mathrm{yr}^{-1}$ during the first $500 \mathrm{yr}$ and about $0.17 \mathrm{~mm} \mathrm{yr}^{-1}$ thereafter.
\end{abstract}

(C) 2015 Elsevier B.V. All rights reserved.

\section{Introduction}

Ice shelves influence ice-sheet dynamics by contributing a back-stress component (buttressing effect), opposing the ice flux from the continent to the ocean, and thus controlling Antarctica's grounded-ice volume which affects the global sea level (e.g., Dupont and Alley, 2005; Joughin et al., 2012). In particular, for the Filchner-Ronne Ice Shelf (FRIS) cavity, ocean general circulation models project a $2 \mathrm{~K}$ warming by the end of the $21 \mathrm{st}$ century, causing a multifold increase of melting at the base of Antarctica's second biggest ice-shelf system (Hellmer et al., 2012; Timmermann and Hellmer, 2013). The FRIS is fed by a number of ice streams, draining catchment basins of the West and East Antarctic Ice Sheets (Fig. 1b). Increased basal melting at the deepest parts of the floating ice shelf would induce thinning and a decrease in buttressing forces to the grounded ice sheet. On the other hand changes in the ice cavity geometry by melting (freezing) influence the ocean circulation regime with enhanced (reduced) ventilation of the cavity. Due to the weak stratification in ice shelf cavities the circulation is steered along constant

\footnotetext{
* Corresponding author.

E-mail address: Malte.Thoma@awi.de (M. Thoma).
}

$f / H$-contours ( $f$ Coriolis force, $H$ water column thickness) and therefore is highly sensitive to water column changes (Grosfeld and Sandhäger, 2004). A subsequent retreat of the grounding line would lead to a reduction of the grounded ice volume and thus a further contribution to global sea level rise. Since large parts of the ice sheet in the investigated area are resting on an inland-sloping bedrock (Ross et al., 2012), ice-dynamic processes could trigger a marine ice-sheet instability (MISI) (Schoof, 2007; Gudmundsson et al., 2012). Such a fast and widespread groundingline retreat may capture particularly regions where grounded ice is based on bedrock far below sea level. This has been assessed from geophysical observations (Ross et al., 2012) for Moeller and Institute Ice Streams (Fig. 1). A recent modelling study (Wright et al., 2014) indicates the vulnerability of this area. In principle, a grounding-line retreat affects ice dynamics due to a change from an ice-sheet to an ice-shelf flow regime. For a given ice geometry, this retreat results in a local loss of basal friction, causing higher ice flow velocities and thus favouring increased ice discharge. A similar process seems to control the speed-up and the retreat of the Pine Island Glacier (Favier et al., 2014). The potential heat flux, provided by the ocean currents beneath the ice shelf, is therefore the principle driver for ice sheet mass loss or instability in Antarctica, as long as surface melt processes do not play a significant role. 

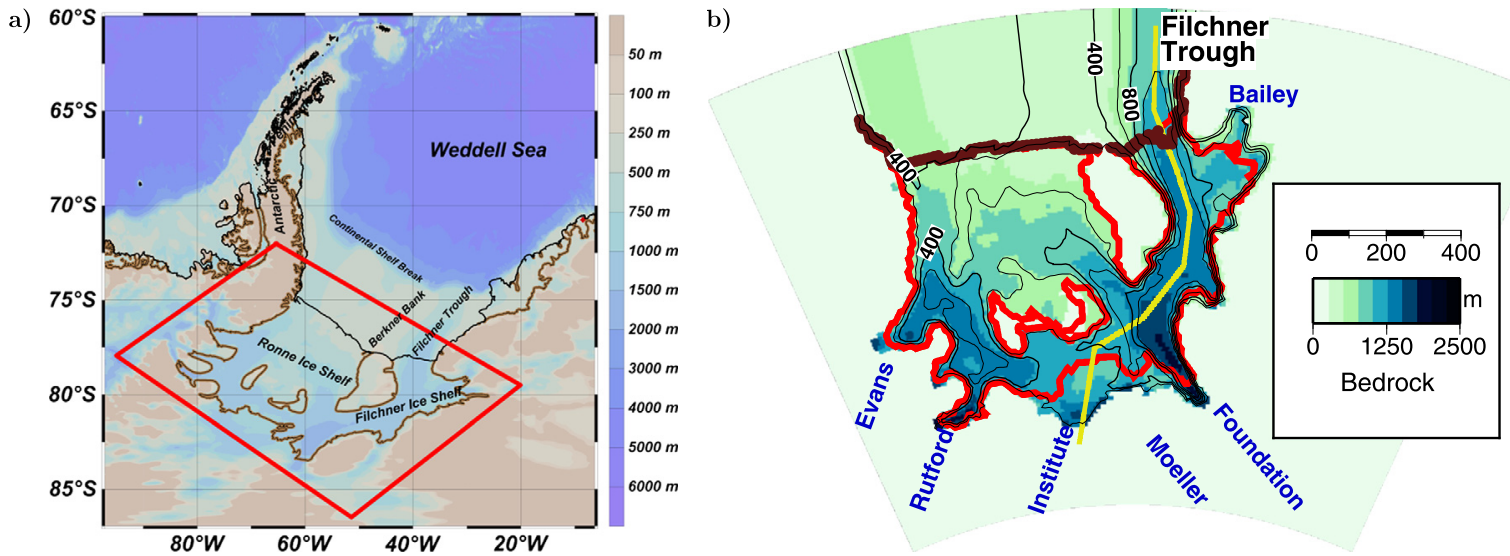

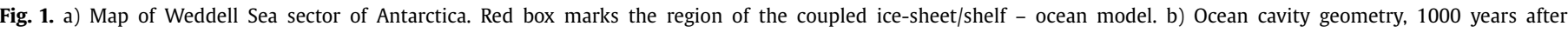

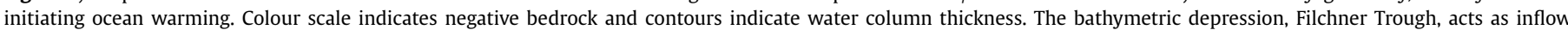

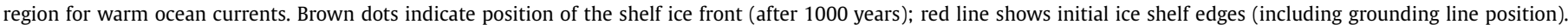
The yellow line indicates the location of the temperature section shown in Fig. 2. Names indicate ice streams feeding the FRIS.

Most studies investigating the impact of climate warming on ice sheet-ice shelf systems, imply a steady-state initial condition. This is achieved by tuning the model's boundary conditions and parameters until the model is able to reproduce the present day observations as close as possible. However, it is arguable if the present day ice sheets can be considered to be in a steady state at all, rather than in a transitional adjustment phase since the last deglaciation. Therefore, we take a different approach here: Instead of tuning our coupled model towards the present day conditions, we use an ensemble approach to estimate the potential impact of ocean warming on the sea level rise.

In our study, we analyse the impact of ocean warming of the FRIS cavity and the corresponding contribution to sea level rise with a fully coupled ice sheet/shelf - ocean model. For this purpose we introduce the applied models and their coupling (Section 2) before we present the results (Section 3). Finally (Section 4), we discuss the implications and compare our results with other findings.

\section{Model setup}

We coupled the ice-flow model RimbaY ${ }^{1}$ (Thoma et al., 2014), and the regional ocean circulation model RomBAX ${ }^{2}$ (Grosfeld et al., 1997; Thoma et al., 2006, 2014) in order to investigate groundingline migration and grounded-ice volume changes in the FRIS region within a centennial time scale following the onset of a high-melt mode. The asynchronous coupling-procedure with RIRoCo ${ }^{3}$ is described in detail in Thoma et al. (2010). Rombax provides heat fluxes necessary to quantify melt rates at the ice-shelf base by simulating the thermohaline circulation within the ice-shelf cavity and the adjacent ocean. Our ice-model domain comprises the presentday area of FRIS as well as near-shore parts of its catchment area, totalling $1.4 \times 10^{6} \mathrm{~km}^{2}$ (Fig. 1a).

\subsection{Ice-sheet-ice-shelf model}

The 3-d ice-flow model Rimbay (Thoma et al., 2014) is applied with a horizontal resolution of $10 \mathrm{~km}$. The model uses the shallowice approximation (SIA) to represent ice-sheet flow dominated by vertical shear, and the shallow-shelf approximation (SSA), which

\footnotetext{
1 Revised Ice sheet Model Based on frAnk pattYn.

2 Revised Ocean Model Based on BryAn and CoX.

3 Rimbay-RombaX-Coupler.
}

utilises longitudinal stresses to simulate ice-shelf spreading. Upstream of the grounding line, a transition zone of $40 \mathrm{~km}$ width allows a numerically smooth change from pure ice-sheet flow to pure ice-shelf flow by interpolating both solutions. The ice rheology, which links the deviatoric stress with the strain rate, is described by Glen's (isotropic) flow law with the exponent $n=3$. Model studies indicate that introducing an enhancement factor to this empirical relationship improves the modelled ice velocities with respect to observations. We apply two different enhancement factors for the ice sheet and ice shelf ( 4.5 and 0.5 , respectively, consistent with Martin et al., 2011), which reflect the different anisotropic characteristics within these ice bodies (Ma et al., 2010).

In general, a horizontal resolution of $10 \mathrm{~km}$ is considered to be too coarse to represent all details of grounding line migration (e.g., Pattyn et al., 2013). If the grid resolution is in the same order of magnitude than the expected grounding line migration, details of the migration can naturally not be resolved (Levermann et al., 2014). However, if the grounding line moves over large distances, this limitation becomes less restrictive. This has been shown for RimbaY in Thoma et al. (2014, Section 6.3), where parts of the first MISMIP (Marine Ice Sheet Model Intercomparison Project) experiment (Pattyn et al., 2012) were successfully repeated. They demonstrated that a $10 \mathrm{~km}$ and even a $20 \mathrm{~km}$ grid resolution is sufficient to reproduce a reversible grounding line migration of about $730 \mathrm{~km}$. Also, Pollard et al. (2015) showed that for glacial/interglacial climate-forcings the differences between $10 \mathrm{~km}, 20 \mathrm{~km}$, and $40 \mathrm{~km}$ grid resolution are negligible in the context of the modelled impact on sea-level rise. In the second MISMIP benchmark (MISMIP-3D, Pattyn et al., 2013), where the GRL moves only about $18 \mathrm{~km}$, it was demonstrated that RIMBAY is able to simulate a reversible grounding line migration and to estimate diagnostic horizontal velocities within acceptable limits, given the low grid resolution and the comparable immobile GRL.

A second issue in the context of grounding line migration modelling is the difference between a coupled SIA/SSA model and higher order models. According to Pattyn et al. (2013) and Feldmann et al. (2014) the response time of SIA/SSA and higherorder models differs. However, with respect to the centennial timescales, on which the ice sheet/shelf responds to climate forcing, the decadal-scale differences between SIA/SSA and higher order models have only a minor influence on our results (Mengel and Levermann, 2014).

Thoma et al. (2014) showed in an extended version of the MISMIP experiment (Pattyn et al., 2012) with a nested higher order or Full Stokes physics zone around the grounding line that RimbaY re- 
sults come close to the theoretical reference state (Schoof, 2007), in particular if the grounding line migrates over a long distance. In addition, Levermann et al. (2014) showed for a strong oceanic forcing that the uncertainties of such a severe change of the boundary conditions mask the uncertainties resulting from different ice models, which might have a higher resolution and/or include higher order terms. With the severe change in ice shelf basal melting we model a maximum GRL migration of $180 \mathrm{~km}$, which is well above the model resolution. With respect to the uncertainties of other atmosphere and ocean modelling issues, like boundary conditions and parameterisations, we consider RimbaY in its present configuration well suited for simulating climate feedbacks of Antarctic ice shelves.

For capturing the dynamics of grounded ice flow, basal sliding is taken into account by the Weertman sliding mechanism (e.g., Cuffey and Paterson, 2010) with a constant basal friction coefficient. Vertically, 41 terrain-following layers resolve the icesheet flow with the highest resolution near the lower boundary. The modelled ice-flux divergence, surface accumulation (Le Brocq et al., 2010), and basal melting or freezing at floating parts (as modelled by the ocean model) determine projected ice-thickness changes within the system. The surface accumulation is kept constant in all experiments described here. According to Wright et al. (2014), it would have to increase significantly more than prognosed in climate scenarios to counteract increased basal melting. Calving is not explicitly modelled here, instead the ice-flux is exported virtually at the ice shelf front. However, Rimbay allows a shelf retreat for a negative flux balance at the ice shelf front, i.e., if basal melting surmounts other flux components. Basal topography and ice thickness (ALBMAP, Le Brocq et al., 2010) yield the position of the grounding line (by means of the flotation criterion), which becomes the southern boundary of the ocean-model component. On the lateral model boundaries, which are not consistent with the drainage basin of the FRIS, the velocities are estimated according to the locally defined SIA, and ice thickness is assumed to be constant. The latter simplification is justified for the only several-century-long ice-sheet evolution evaluated in this study, as ice thickness along the edges of the model domain decreases only by a few meters (less than 1\%), which can be ignored in the context of sea-level rise. With this setup Rimbay is able to model the general features of the observed flow pattern (Rignot et al., 2011) without any additional tuning within acceptable limits (see supplemental material).

\subsection{Ocean model}

We use the primitive equation, general circulation ocean model RомвAX, which has been used in several applications to simulate the circulation and ice-ocean interaction in ice-shelf cavities and the adjacent ocean (Determann and Gerdes, 1994; Grosfeld et al., 1997; Grosfeld and Sandhäger, 2004; Thoma et al., 2006, 2014). In the current study, RomBAx is applied in a horizontal resolution of $0.1^{\circ} \times 0.3^{\circ}$, corresponding to grid cells of about $11 \mathrm{~km} \times 8 \mathrm{~km}$ at $75^{\circ} \mathrm{S}$. In the vertical, 15 terrain-following layers resolve the water column within the ice shelf cavity, and four additional surface layers of constant thickness (each $25 \mathrm{~m}$ ) in the open ocean prevent a pressure gradient error at the steep ice front (Grosfeld et al., 1997). The minimum layer thickness within the cavity is forced to be at least $1 \mathrm{~m}$, but most layers are in the order of 10 to $50 \mathrm{~m}$ thick. The maximum layer thickness is about $102 \mathrm{~m}$. North of the calving front, Rombax's model domain is extended by an open-ocean region of about 50 to $100 \mathrm{~km}$ width (Fig. 1).

At the northern edge of the ocean domain an open boundary serves as a gate for the climate signal by prescribed inflow of a warm ocean current. At inflow regions, ocean temperature and salt are restored (nudged) to prescribed conditions and advected into the model domain by the prescribed vertically integrated mass transport stream function. At outflow regions, the prescribed stream function advects heat and salt out of the model domain. During the model spin-up, potential temperature $(\Theta)$, and salinity $(S)$, are kept constant along this northern boundary (compare Fig. 2).

Wind stress is neglected as well as sea-ice growth and decay so that seasonal variations are suppressed. Instead, annual mean surface temperature and salinity are restored to $-1.89^{\circ} \mathrm{C}$ and 34.45 , respectively. The latter is more saline than austral summer measurements, but represents an annual mean value (Årthun et al., 2012). This simplifies the model setup and its interpretation, as annual cycles are expected to be a secondary effect only, compared to the impact of the strong and warm inflow at the open-ocean boundary analysed in this study.

In general, the major driving mechanism for ice-ocean interaction within the ice-shelf cavity is the heat exchange across the ice-ocean boundary (e.g., Lewis and Perkin, 1986). Relatively warm currents with respect to the in-situ freezing point (Foldvik and Kvinge, 1974) provide heat for melting, become fresher and more buoyant and tend to rise into shallower areas. Here, being supercooled with respect to the in-situ freezing point of this less-deep boundary, the water has the potential to form ice platelets, which accrete at the ice-shelf base. In RomBAx, the process of ice-ocean interaction is parametrised according to a three-equation formulation (e.g., Holland and Jenkins, 1999).

The Filchner Trough serves as the main exchange route for water masses of the Weddell Sea slope current and the FRIS cavity. The trough ends at the continental shelf break with a $600 \mathrm{~m}$ deep sill, where presently Ice Shelf Water (ISW) colder than $-1.9^{\circ} \mathrm{C}$ leaves the trough at the bottom of its western flank (e.g., Grosfeld et al., 2001; Foldvik et al., 2004). Modified Warm Deep Water (MWDW) enters the Filchner Trough at its eastern flank with a seasonal cycle, ranging from $0{ }^{\circ} \mathrm{C}$ during summer to $-1.5^{\circ} \mathrm{C}$ during winter (Årthun et al., 2012). Recent findings derived from CTDsections and mooring data by Darelius et al. (2014) and modelling efforts by Makinson et al. (2011) suggest that the classical view of a deep cyclonic circulation of Ice Shelf Water (ISW) (Carmack and Foster, 1975) might be revised into a flow which turns eastward, leaving the ice-shelf cavity, and crosses the sill at the eastern flank of the Filchner Trough.

As a response to climate warming, according to the IPCC AR4 (Bernstein et al., 2007) scenario $\mathrm{A} 1 \mathrm{~B}$ (atmospheric $\mathrm{CO}_{2}$ reaches $700 \mathrm{ppm}$ by the year 2100), ocean-model simulations project the intrusion of Warm Deep Water (WDW) of circumpolar origin into the Filchner Trough at rates of $2.5-4.0 \mathrm{~Sv}\left(1 \mathrm{~Sv}=10^{6} \mathrm{~m}^{3} \mathrm{~s}^{-1}\right)$. In order to trigger a high-melt phase in our simulations, we instantly raise potential temperatures of the deep inflow to $0.1^{\circ} \mathrm{C}$ and salinity to 34.75 , following the projections of two coupled sea-ice-ocean models (Hellmer et al., 2012; Timmermann and Hellmer, 2013). A prescribed mass transport of $3.0 \mathrm{~Sv}$ at the northern boundary off the Filchner Trough induces a southward flow of these warm waters, guiding them through the trough underneath the ice shelf (Fig. 2b). To the west, in front of the Ronne Ice Shelf, only a $\theta, S$-restoring to climatological values is performed. In general, the modelled circulation beneath the FRIS (not shown) is in agreement with the results presented by Grosfeld and Gerdes (1998) and Gerdes et al. (1999), who used a predecessor of RomBAx. By neglecting the influence of wind and sea-ice effects, all changes in the ocean-ice-shelf interaction can be traced back to the postulated warm flow into the Filchner Trough.

\subsection{Model coupling, model spin-up and ensemble mean approach}

Before the ice sheet is allowed to evolve freely, Rimbay is run for 1000 years with a fixed geometry to adjust the thermal 

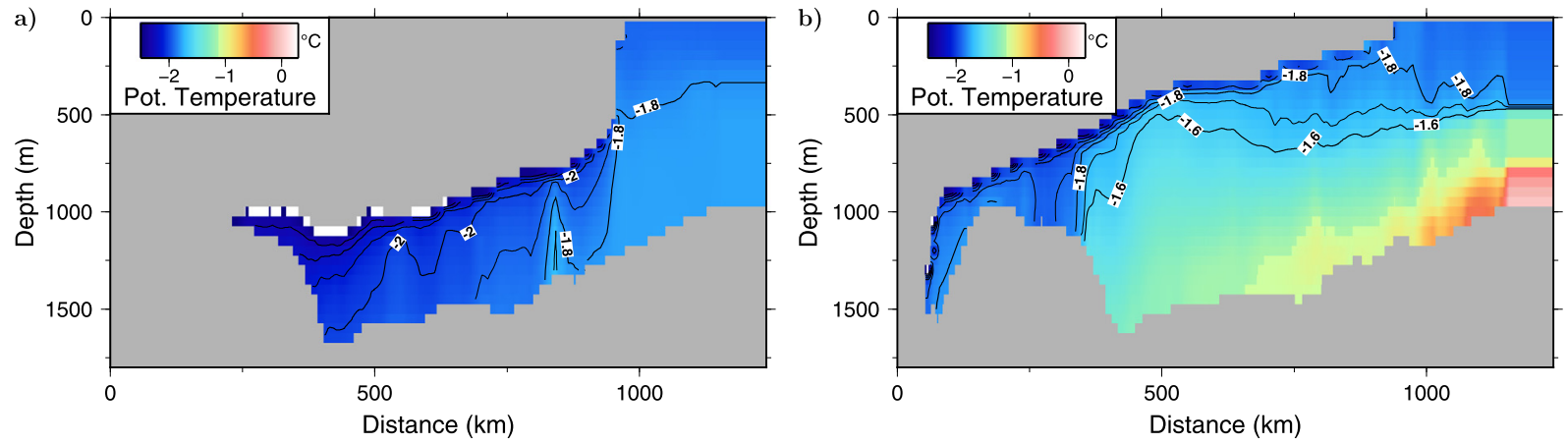

Fig. 2. Transect of potential temperature along the yellow line shown in Fig. 1 during the first 1000 years (left) and after warming occurred for 900 years.

regime within the ice to the given boundary conditions. Afterwards, the full coupling between the ice sheet/shelf model RimBAY and the ocean model Rombax is performed by the coupler RIRoCo (Thoma et al., 2010): After 50 years (or even less for the early cycles) of ice thickness evolution, the cavity geometry is passed to the ocean model Rombax, which is integrated for about 8 model years until a quasi steady state of the basal melting is reached. The estimated basal mass balance is passed back via RIRoCo to the ice model RIMBAY, which now evolves according to the updated boundary conditions. This asynchronous coupling procedure is sufficient as ice and ocean models evolve on different time scales. A similar approach has been applied by Grosfeld and Sandhäger (2004), who modelled an idealised coupled ice-ocean system. The exact timing of the grounding line migration (retreat) is of minor importance for the potential of additional sea-level contribution, therefore, we choose coupling cycles between 10 and 50 years. Fig. 3a shows discontinuous changes in basal mass balance in the order of $10 \mathrm{~km}^{3} / \mathrm{yr}$, which is less than $10 \%$ of the total amount. The figure also shows an asymptotic behaviour of the basal mass balance change during the evolution (lower steps towards the end of the simulation) and a smooth evolution of the ice shelf area and ice volume. This indicates that the choice of the coupling cycles is sufficient.

To estimate the impact of ocean warming on the fully coupled system, the unwarmed control run is continued until model year 2200. An ensemble of nine climate sensitivity experiments is created by inducing ocean warming according to the method described in Section 2.2, every 100 years between model year 1100 and 1900. The ensemble members differ by their initial state (e.g., ice volume, grounding line position). A comparison between the control run (Fig. 3a) and the warming scenarios for corresponding years after the warming has been initiated, allows to project the climate impact on the ice shelf, while the FRIS is in a transient state (see Section 3).

\section{Results}

Previous applications with the predecessor of Rombax (Grosfeld and Gerdes, 1998; Gerdes et al., 1999) showed that the modelled basal mass balance of FRIS is consistent with evidence of marine ice beneath the ice shelf (e.g., Grosfeld et al., 1998; Sandhäger et al., 2004). The spatial pattern and the magnitude of the basal mass balance of the control experiment (Fig. 4a) is in agreement with these earlier studies and with recent results of the finite element ocean model FESOM (Timmermann et al., 2012; Timmermann and Hellmer, 2013). Highest melt rates occur near the Filchner Ice Shelf front and near the grounding lines of deep troughs, corresponding to ice stream estuaries. However, in our model this ice loss is only partly compensated by surface accumulation and ice flux from the inner ice sheet. Since it is unknown whether the FRIS is in steady state or not we run our model with- out any tuning of basal sliding or ice viscosity. (Recent mass balance estimates derive a slightly positive mass balance, e.g., Paolo et al., 2015.) The simulated volume and ice shelf area are increasing slightly by about $3.3 \%$ and $6.9 \%$ within 1000 years, respectively (Fig. 3a). This is in general agreement with the results of Wright et al. (2014), who modelled the same region, but with a very different approach (see discussion in Section 4). Note that in the control run, the initial basal melting (model year 1000) is significantly higher than after some coupling cycles, due to an ice thinning and corresponding adjustment of the ocean circulation (Fig. 3a).

After ocean warming at the inflow of the Filchner Trough is initiated, according to projected climate change impacts (Hellmer et al., 2012; Timmermann and Hellmer, 2013), melting at the ice shelf base increases dramatically (Figs. 3a, b and $4 \mathrm{~b}$ ). The impact of ocean warming on the coupled ice-ocean system can be evaluated by comparing the warming experiments with the (unwarmed, but coupled) control experiment after corresponding years of evolution. Fig. 3 shows the transient control experiment and anomalies between the ensemble mean results plus the standard deviation for the individual ensemble members. Thus, the impact of the warming signal can be separated from the transient state of the coupled system.

The ocean warming results in a distinct increase of the basal mass loss by about $125 \mathrm{~km}^{3} / \mathrm{yr}$ (i.e., doubling the former value) for about 500 years (Fig. 3a, b and Fig. 4). This reverses the volume gain of about $0.33 \%$ within the first 100 years of the control experiment to a volume loss of about $0.75 \%$ within 100 years of the warming experiments and has consequences for the ice-shelf geometry (Fig. 5a) and ice-flow velocities (Fig. 5b) of the coupled icesheet/shelf system. Because of ocean warming, the grounding line retreats faster between Moeller and Institute Ice Streams (compare Fig. 1), possibly reaching an ancient position, as suggested by Ross et al. (2012). Observed sediment layers in this submarine basin indicate a former deglaciation of the area. The regions with highest basal melt rates follow the retreating grounding line (Figs. 2 and 4). The FRIS area increases by about $25000 \mathrm{~km}^{2}$ within 700 years (Fig. 3c), representing a growth of about $6 \%$ compared to the present-day value of about $435000 \mathrm{~km}^{2}$ (compare Fig. 3a at the beginning of coupling cycles). This increase is twice as much as was anticipated by estimates of historical grounding-line positions according to the bedrock characteristics of the concerned reverseslope basin (Ross et al., 2012). The only other region, where a significant grounding line retreat takes place is further north in the area of the Bailey Ice Stream.

Compared to the control run, the ice thickness decreases by more than $100 \mathrm{~m}$ within large parts of the Filchner Ice Shelf and more than $1000 \mathrm{~m}$ in the newly formed ice shelf areas between the Moeller-Institute Ice Streams and at the Foundation and Bailey Ice Streams (Fig. 5a). The change from grounded ice (with velocities of less than $50 \mathrm{~m} \mathrm{yr}^{-1}$ ) towards floating ice is accompanied by an ice flow acceleration of more than $500 \mathrm{~m} \mathrm{yr}^{-1}$, demonstrat- 

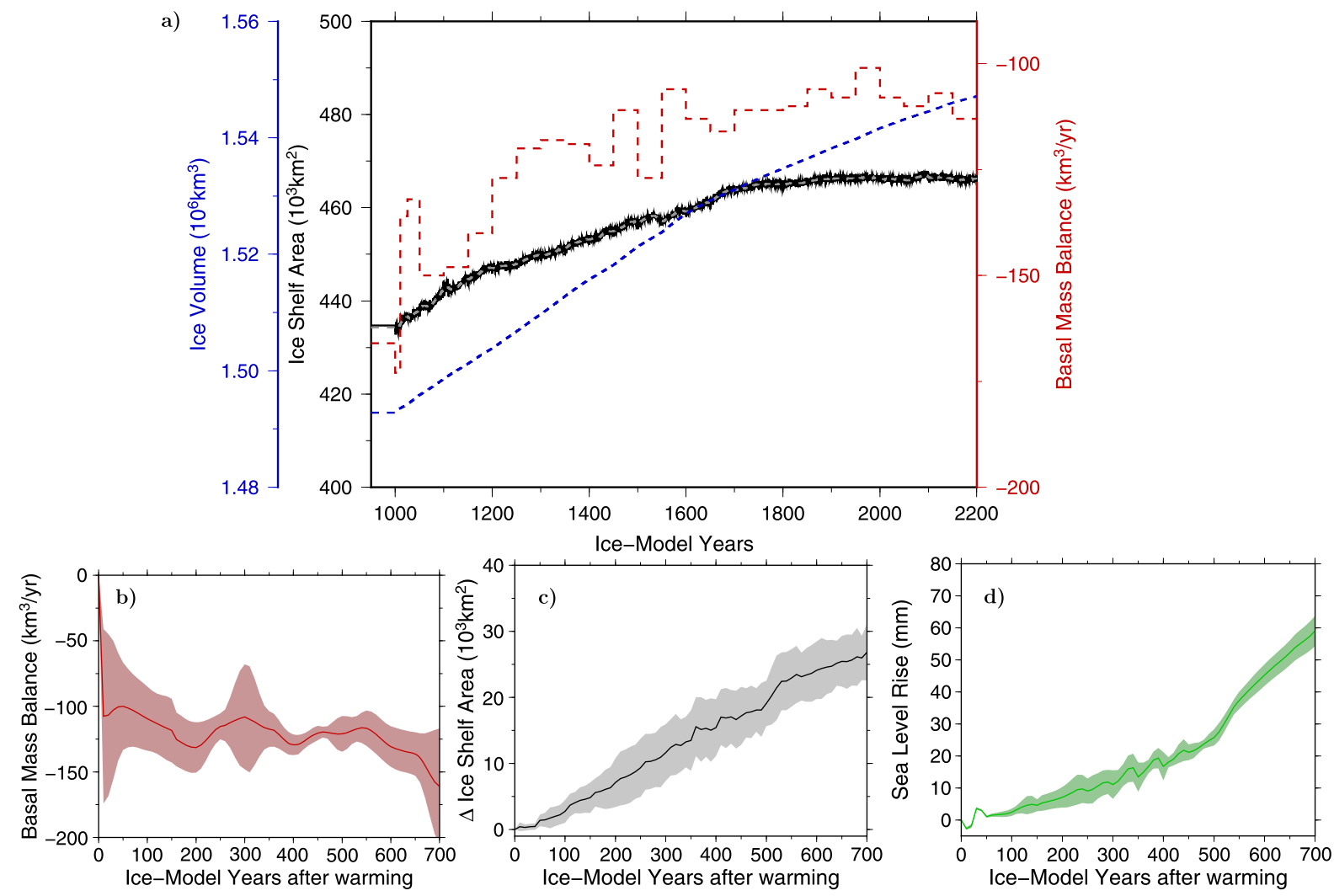

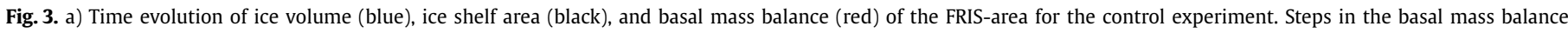

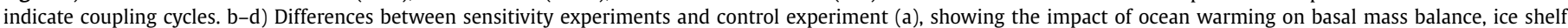

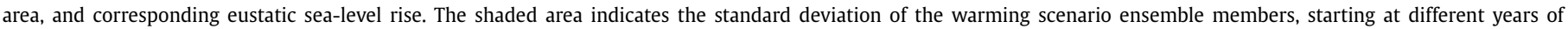
the control experiment.
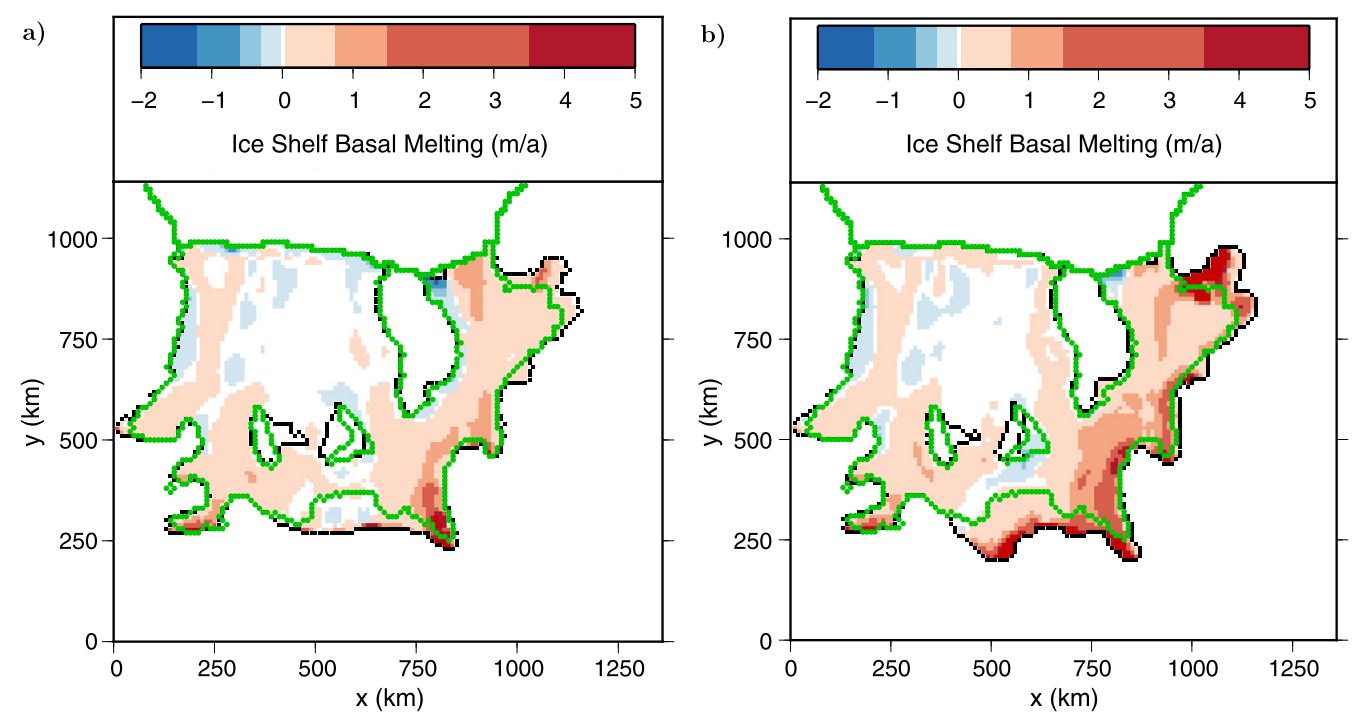

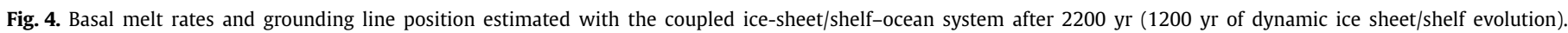
The green lines indicate the initial grounding line position. a) Control experiment, b) Warming (initiated after 1100 model years) experiment.

ing the response of ice dynamics on a melt-induced grounding-line retreat (Fig. 5b).

\section{Discussion and conclusion}

A common approach when modelling the impact of climate (in this case ocean) warming on the climate system (in this case on the FRIS and its hinterland) is to start from a quasi steady state, which represents the current conditions as close as possible to observations, and to analyse the deviation in response to changing boundary conditions. However, this assumption might be problematic for two reasons. First, if a numerical model does not reproduce the current observed state of a considered system with its inherent physics and has to be forced towards it by tuning of model parameters (which is most often the case), there is no guarantee that (a) these parameters are also valid for different boundary conditions 

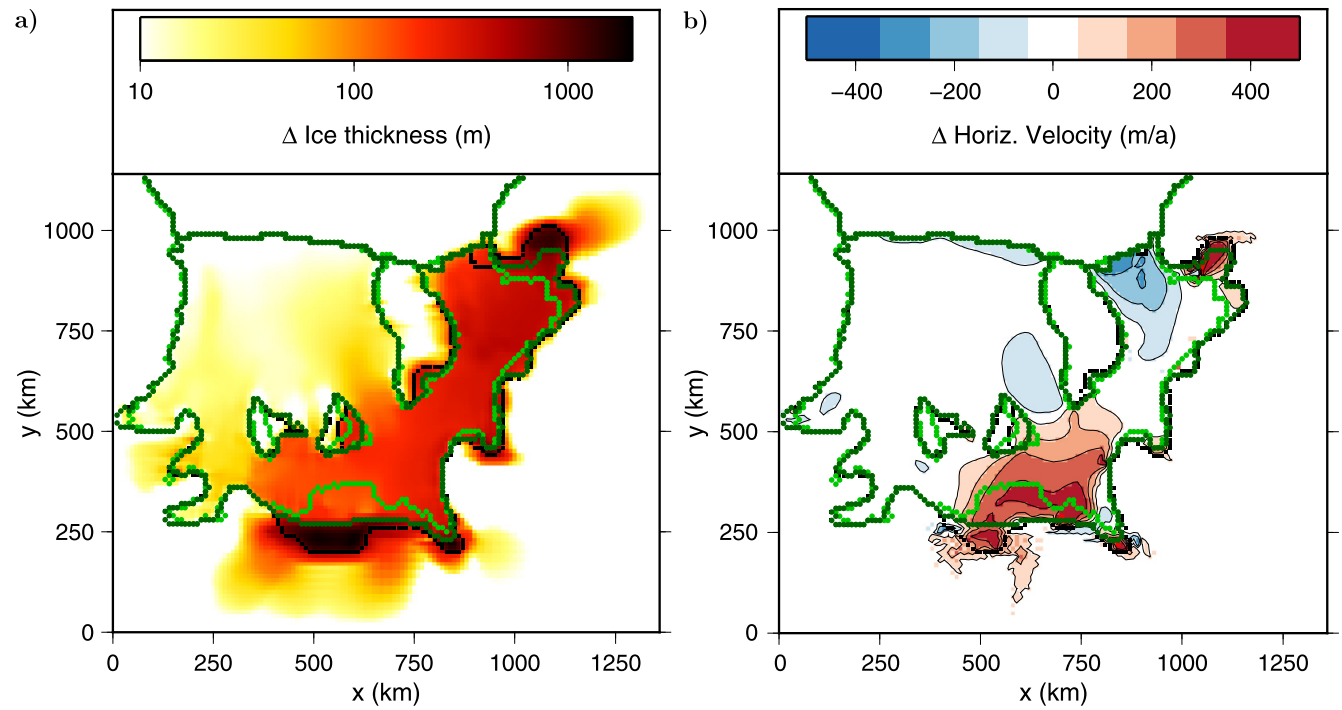

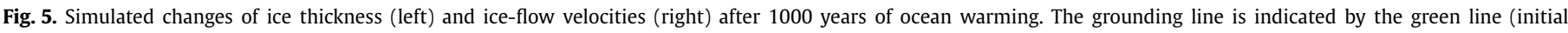

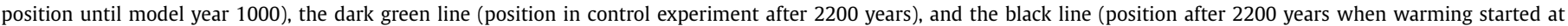
year 1100).

and (b) the model's response to changing boundary conditions is correct. Second, for slowly varying systems like ice bodies it is not clear if they are in a steady state in the first place at all. Adjustment processes of ice dynamics, sea level, and solid Earth on glacial-interglacial time scales, especially in response to changes since the last deglaciation, are long-term transient processes and cannot be considered as completed.

In this context, we would like to refer to the study of Wright et al. (2014), who modelled the same region (FRIS) with the same question (impact of ocean warming), but with a very different approach: Wright et al. (2014) tuned their ice model (BISICLES) by inverting observed surface velocities and a prescribed 3D-temperature field from Pattyn (2010) for the effective viscosity and basal traction. The basal mass balance for their ice shelf is then derived from mass divergence, assuming steady state conditions. In addition, BISICLES uses an adaptive mesh refinement around the grounding line to represent its possible migration as good as possible. Because of the applied inversion, their modelled ice velocities are in good agreement with observations. However, despite all these efforts, the initial (observed) grounding line position is not stable and significant ice thickness adjustments of several hundred meters occur during their 2000-year model run (see Fig. 5a in Wright et al., 2014). This is in general agreement with our findings, as for our not-tuned ice model RimBAY the initial FRIS domain is not in steady state for the current boundary conditions, too.

This might indicate, that either (a) the applied boundary conditions (e.g., surface mass balance, surface temperature, basal mass balance, bedrock topography) have deficits, (b) the model physics and parameterisations (which are quite different in both models) do not represent the real-world physics sufficiently, or (c) the currently observed FRIS is not in steady state but rather in a transition phase.

Nevertheless, despite all model limitations, it is possible to estimate the impact of climate change on the FRIS domain by comparing warming scenarios with an un-warmed control experiment. Wright et al. (2014) scaled the present day basal mass balance by simple linear multiplication of the present-day basal mass balance pattern and by extrapolation into formerly grounded areas to simulate ocean warming. However, this approach is limited as it cannot represent the dynamic response of the ocean to a modified cavity geometry, which leads to a pattern shift. Furthermore, former freezing areas might not survive if the amount of provided heat exceeds the melting capability near the deep grounding line or areas of melting might turn into freezing areas (Fig. 4). Therefore, the complex 3D-geometry beneath the FRIS demands a highly resolved (in the order of $10 \mathrm{~km}$ ) ocean model to derive the basal melt (and freeze) pattern, which is interactively coupled with the overlying ice shelf. Our coupled modelling approach shows that ocean circulation and melt regions follow a migrating grounding line. This key process of a marine-based ice-sheet erosion cannot be mapped by any simple parametrisation of sub-ice-shelf melting which ignores the highly dynamic feedback between ice and ocean as mentioned above. This kind of parametrisation might resolve an average basal melt rate but fails to find and quantify hot spots at potentially vulnerable areas like the grounding line. Also, a parametrisation which neglects the feedback of melt water on the circulation might tend to overestimate the total melt volume.

The strongest impact of ocean warming is found in the areas of Bailey and Foundation Ice Streams as well as in the area between Moeller and Institute Ice Streams, where the ice thickness reduction of (formerly) grounded ice is accompanied by an increase of ice velocity, draining the hinterland.

The impact on sea level rise $\zeta(t)$ due to an ice volume change $(\Delta V)$ can be estimated from the changes in ice thickness $(\Delta H)$, with special consideration of grounded ice below sea level where bedrock $(B)$ is negative:

$\zeta(t)=-\frac{\rho_{\mathrm{I}}}{\rho_{\mathrm{O}}} \frac{\Delta x \Delta y}{A_{0}} \begin{cases}\Delta H & \text { if } B \geq 0 \\ \Delta H+\frac{\rho_{\mathrm{O}}}{\rho_{\mathrm{I}}} B & \text { if } \quad B<0\end{cases}$

with the densities of ice $\left(\rho_{\mathrm{I}}\right)$ and ocean $\left(\rho_{\mathrm{O}}\right)$, the ocean area $A_{0}$, and the horizontal grid dimensions $\Delta x$ and $\Delta y$. The impact of the ice loss, resulting from ocean warming, is shown in Fig. 3d. We estimate an additional sea level rise of about $5 \mathrm{~mm}$ per $100 \mathrm{yr}$ for the first 500 years, and a distinct increase of about $17 \mathrm{~mm}$ per $100 \mathrm{yr}$ thereafter. This substantial increase results from the ice thickness reduction between Moeller and Institute Ice Streams caused by the grounding line retreat in this area (Figs. 5a and 3b). These values are similar to the results of Wright et al. (2014), who concluded that the FRIS sector has the potential to contribute to sea level raise by about $0.3 \mathrm{~m}$ in $2000 \mathrm{yr}$, which is equivalent to $15 \mathrm{~mm}$ per $100 \mathrm{yr}$.

We would like to emphasise that a higher ice- and ocean model resolution, in particular in the vicinity of the GRL would certainly 
reduce the uncertainties of the presented results. An improved representation of ice dynamics within our model could support a faster grounding-line migration within shorter time spans in conjunction with a faster sea-level rise. To quantify this, future simulations should better resolve ice-stream dynamics, especially basal frictional processes governed by, e.g., lubrication through subglacial water (Goeller et al., 2013). Such an approach could reproduce fast-flowing glaciers with their potential to drain the ice sheet faster. The hypothesis of marine ice sheet instability (Mercer, 1978) gets only partial support from our model results because the phenomenon is confined to one extensive basin (between the Institute and Moeller Ice Streams) under the FRIS catchment. At present, the Weddell Sea sector of the West Antarctic Ice Sheet might represent an intermediate state between a glacial and an interglacial extent. Current climate change will last at least for several hundred years (e.g., Solomon et al., 2009), but it needs to be proven whether prolonged high-melt conditions under FRIS might lead to a disintegration of vast areas of the West Antarctic Ice Sheet. In any case, our study calls for fully coupled ice sheet/shelf-ocean models providing the ability to include the full feedback of the coupled climate system.

\section{Acknowledgements}

This work was funded by the DFG through grant TH 1136/1-1 and partially supported by funding to the ice2sea programme from the European Union 7th Framework Programme, grant No. 226375. Here it is ice2sea publication number ice2sea161. This work also contributes to the Helmholtz Climate Initiative REKLIM (Regional Climate Change), a joint research project of the Helmholtz Association of German Research Centres (HGF). The authors wish to thank Ralph Timmermann for fruitful discussions, Rüdiger Gerdes for his support, and two anonymous reviewers for helpful comments which improved the quality of the manuscript.

\section{Appendix A. Supplementary material}

Supplementary material related to this article can be found online at http://dx.doi.org/10.1016/j.epsl.2015.09.013.

\section{References}

Årthun, M., Nicholls, K.W., Makinson, K., Fedak, M.A., Boehme, L., 2012. Seasonal inflow of warm water onto the southern Weddell Sea continental shelf, Antarctica. Geophys. Res. Lett. 39 (17), 1-6.

Bernstein, L., Bosch, P., Canziani, O., Chen, Z., Christ, R., Davidson, O., Hare, W. Huq, S., Karoly, D., Kattsov, V., Kundzewicz, Z., Liu, J., Lohmann, U., Manning M., Matsuno, T., Menne, B., Metz, B., Mirza, M., Nicholls, N., Nurse, L., Pachauri, R., Palutikof, J., Parry, M., Qin, D., Ravindranath, N., Reisinger, A., Ren, J., Riahi, K., Rosenzweig, C., Rusticucci, M., Schneider, S., Sokona, Y., Solomon, S., Stott, P., Stouffer, R., Sugiyama, T., Swart, R., Tirpak, D., Vogel, C., Yohe, G., Allali, A., Bojariu, R., Diaz, S., Elgizouli, I., Griggs, D., Hawkins, D., Hohmeyer, O., Jallow, B.P., Kajfez-Bogataj, L., Leary, N., Lee, H., Wratt, D., 2007. Climate Change 2007: Synthesis Report. Intergovernmental Panel on Climate Change, iPCC, AR4.

Carmack, E.C., Foster, T.D., 1975. Circulation and distribution of oceanographic properties near the Filchner Ice Shelf. Deep-Sea Res. 22, 77-90.

Cuffey, K.M., Paterson, W.S.B., 2010. The Physics of Glaciers, 4th edition. Elsevier Oxford.

Darelius, E., Makinson, K., Daae, K., Fer, I., Holland, P.R., Nicholls, K.W., 2014. Hydrography and circulation in the Filchner depression, Weddell Sea, Antarctica. J. Geophys. Res. 119 (9), 5797-5814

Determann, J., Gerdes, R., 1994. Melting and freezing beneath ice shelves: implications from a 3-d ocean circulation model. Ann. Glaciol. 20, 413-419.

Dupont, T.K., Alley, R.B., 2005. Assessment of the importance of ice-shelf buttressing to ice-sheet flow. Geophys. Res. Lett. 32, L04503.

Favier, L., Durand, G., Cornford, S.L., Gudmundsson, G.H., Gagliardini, O., GilletChaulet, F., Zwinger, T., Payne, A.J., Le Brocq, A.M., 2014. Retreat of Pine Island Glacier controlled by marine ice-sheet instability. Nature Clim. Change 4 (2), 117-121.
Feldmann, J., Albrecht, T., Khroulev, C., Pattyn, F., Levermann, A., 2014. Resolutiondependent performance of grounding line motion in a shallow model compared with a full-Stokes model according to the MISMIP3d intercomparison. J. Glaciol. 60 (220), 353-360.

Foldvik, A., Gammelsrød, T., Østerhus, S., Fahrbach, E., Rohardt, G., Schröder, M., Nicholls, K.W., Padman, L., Woodgate, R.A., 2004. Ice shelf water overflow and bottom water formation in the southern Weddell Sea. J. Geophys. Res. 109 (C2), $1-15$.

Foldvik, A., Kvinge, T., 1974. Conditional instability of sea water at the freezing point. Deep-Sea Res. 21, 169-197.

Gerdes, R., Determann, J., Grosfeld, K., 1999. Ocean circulation beneath filchnerronne ice shelf from three-dimensional model results. J. Geophys. Res. C 7, 15827-15841.

Goeller, S., Thoma, M., Grosfeld, K., Miller, H., 2013. A balanced water layer concept for subglacial hydrology in large-scale ice sheet models. Cryosphere 7 (4), 1095-1106.

Grosfeld, K., Gerdes, R., 1998. Circulation beneath the Filchner Ice Shelf and its sensitivity to changes in the oceanic environment: a case study. Ann. Glaciol. 27, 99-104.

Grosfeld, K., Gerdes, R., Determann, J., 1997. Thermohaline circulation and interaction beneath ice shelf cavities and the adjacent open ocean. J. Geophys. Res. 102 (C7), 15595-15610.

Grosfeld, K., Hellmer, H.H., Jonas, M., Sandhäger, H., Schulte, M., Vaughan, D.G., 1998. Marine ice beneath Filchner ice shelf: evidence from a multi-disciplinary approach. Antarct. Res. Ser. 75, 319-339.

Grosfeld, K., Sandhäger, H., 2004. The evolution of a coupled ice shelf - ocean system under different climate states. Glob. Planet. Change 42, 107-132. http://dx.doi.org/10.1016/j.gloplacha.2003.11.04.

Grosfeld, K., Schröder, M., Fahrbach, E., Gerdes, R., Mackensen, A., 2001. How iceberg calving and grounding change the circulation and hydrography in the Filchner Ice Shelf-ocean system. J. Geophys. Res. 106 (C5), 9039-9055.

Gudmundsson, G.H., Krug, J., Durand, G., Favier, L., Gagliardini, O., 2012. The stability of grounding lines on retrograde slopes. Cryosphere 6 (6), 1497-1505.

Hellmer, H.H., Kauker, F., Timmermann, R., Determann, J., Rae, J., 2012. An uncertain future for a large Antarctic ice shelf. Nature 3 (4), 433-442.

Holland, D.M., Jenkins, A., 1999. Modeling thermodynamic ice-ocean interaction at the base of an ice shelf. J. Phys. Oceanogr. 29, 1787-1800.

Joughin, I., Alley, R.B., Holland, D.M., 2012. Ice-sheet response to oceanic forcing. Science 338 (6111), 1172-1176.

Le Brocq, A.M., Payne, A.J., Vieli, A., 2010. An improved Antarctic dataset for high resolution numerical ice sheet models (ALBMAP v1). Earth Syst. Sci. Data Discus. 3 (1), 195-230.

Levermann, A., Winkelmann, R., Nowicki, S., Fastook, J.L., Frieler, K., Greve, R. Hellmer, H.H., Martin, M.A., Meinshausen, M., Mengel, M., Payne, A.J., Pollard, D., Sato, T., Timmermann, R., Wang, W.L., Bindschadler, R.A., 2014. Projecting Antarctic ice discharge using response functions from searise ice-sheet models. Earth Syst. Dyn. 5 (2), 271-293.

Lewis, E.L., Perkin, R.G., 1986. Ice pumps and their rates. J. Geophys. Res. 91 (C10), 11756-11762.

Ma, Y., Gagliardini, O., Ritz, C., Gillet-Chaulet, F., Durand, G., Montagnat, M., 2010. Enhancement factors for grounded ice and ice shelves inferred from an anisotropic ice-flow model. J. Glaciol. 56 (199), 805-812.

Makinson, K., Holland, P.R., Jenkins, A., Nicholls, K.W., Holland, D.M., 2011. Influence of tides on melting and freezing beneath Filchner-Ronne ice shelf, Antarctica. Geophys. Res. Lett. 38 (6), 1-6.

Martin, M.A., Winkelmann, R., Haseloff, M., Albrecht, T., Bueler, E., Khroulev, C., Levermann, A., 2011. The Potsdam parallel ice sheet model (PISM-PIK) - Part 2: dynamic equilibrium simulation of the Antarctic ice sheet. Cryosphere 5 (3), 727-740.

Mengel, M., Levermann, A., 2014. Ice plug prevents irreversible discharge from East Antarctica. Nature Clim. Change 4 (6), 451-455.

Mercer, J.H., 1978. West Antarctic ice sheet and $\mathrm{CO}_{2}$ greenhouse effect: a threat of disaster. Nature 271, 321-325. http://dx.doi.org/10.1038/271321a0.

Paolo, F.S., Fricker, H.A., Padman, L., 2015. Volume loss from Antarctic ice shelves is accelerating. Science 348 (6232), 327-331.

Pattyn, F., 2010. Antarctic subglacial conditions inferred from a hybrid ice sheet/ice stream model. Earth Planet. Sci. Lett. 295 (3-4), 451-461.

Pattyn, F., Perichon, L., Durand, G., Favier, L., Gagliardini, O., Hindmarsh, R.C.A., Zwinger, T., Albrecht, T., Cornford, S., Docquier, D., Fürst, J.J., Goldberg, D., Gudmundsson, G.H., Humbert, A., Hutten, M., Huybrechts, P., Jouvet, G., Kleiner, T., Larour, E., Martin, D., Morlighem, M., Payne, A.J., Pollard, D., Rückamp, M., Rybak, O., Seroussi, H., Thoma, M., Wilkens, N., 2013. Grounding-line migration in plan-view marine ice-sheet models: results of the ice2sea mismip3d intercomparison. J. Glaciol. 59, 215.

Pattyn, F., Schoof, C., Perichon, L., Hindmarsh, R.C.A., Bueler, E., de Fleurian, B., Durand, G., Gagliardini, O., Gladstone, R., Goldberg, D., Gudmundsson, G.H., Huybrechts, P., Lee, V., Nick, F.M., Payne, A.J., Pollard, D., Rybak, O., Saito, F., Vieli, A., 2012. Results of the Marine ice sheet model intercomparison project, MISMIP. Cryosphere 6 (3), 573-588. 
Pollard, D., DeConto, R.M., Alley, R.B., 2015. Potential Antarctic ice sheet retreat driven by hydrofracturing and ice cliff failure. Earth Planet. Sci. Lett. 412, $112-121$.

Rignot, E., Mouginot, J., Scheuchl, B., 2011. Ice flow of the Antarctic ice sheet. Science 333 (6048), 1427-1430.

Ross, N., Bingham, R.G., Corr, H.F.J., Ferraccioli, F., Jordan, T.A., Le Brocq, A., Rippin, D.M., Young, D., Blankenship, D.D., Siegert, M.J., 2012. Steep reverse bed slope at the grounding line of the Weddell Sea sector in West Antarctica. Nat. Geosci. 5, 393-396.

Sandhäger, H., Vaughan, D.G., Lambrecht, A., 2004. Meteoric, marine and total ice thickness maps of Filchner-Ronne-Schelfeis, Antarctica. FRISP Report 15.

Schoof, C., 2007. Ice sheet grounding line dynamics: steady states, stability, and hysteresis. J. Geophys. Res. 112 (F3), 1-19.

Solomon, S., Plattner, G.-K., Knutti, R., Friedlingstein, P., 2009. Irreversible climate change due to carbon dioxide emissions. Proc. Natl. Acad. Sci. 106 (6), 1704-1709.

Thoma, M., Grosfeld, K., Barbi, D., Determann, J., Goeller, S., Mayer, C., Pattyn, F., 2014. Rimbay - a multi-approximation 3D ice-dynamics model for comprehensive applications: model description and examples. Geosci. Model Dev. 7 (1), $1-21$.

Thoma, M., Grosfeld, K., Lange, M.A., 2006. Impact of the Eastern Weddell ice shelves on water masses in the eastern Weddell Sea. J. Geophys. Res. 111 (C12010). http://dx.doi.org/10.1029/2005JC003212.

Thoma, M., Grosfeld, K., Mayer, C., Pattyn, F., 2010. Interaction between ice sheet dynamics and subglacial lake circulation: a coupled modelling approach. Cryosphere 4 (1), 1-12.

Timmermann, R., Hellmer, H.H., 2013. Southern ocean warming and increased ice shelf basal melting in the twenty-first and twenty-second centuries based on coupled ice-ocean finite-element modelling. Ocean Dyn. 63 (9-10), 1011-1026.
Timmermann, R., Wang, Q., Hellmer, H., 2012. Ice-shelf basal melting in a global finite-element sea-ice/ice-shelf/ocean model. Ann. Glaciol. 53 (60), 303-314.

Wright, A.P., Le Brocq, A.M., Cornford, S.L., Bingham, R.G., Corr, H.F.J., Ferraccioli, F., Jordan, T.A., Payne, A.J., Rippin, D.M., Ross, N., Siegert, M.J., 2014. Sensitivity of the Weddell Sea sector ice streams to sub-shelf melting and surface accumulation. Cryosphere 8 (6), 2119-2134.

\section{Further reading}

Anandakrishnan, S., Alley, R.B., Jacobel, R.W., Conway, H., 2001. The flow regime of ice stream $C$ and hypotheses concerning its recent stagnation. In: Alley, R.B. Bindschadler, R.A. (Eds.), The West Antarctic Ice Sheet: Behavior and Environment. American Geophysical Union, pp. 283-296.

Catania, G.A., Scambos, T.A., Conway, H., Raymond, C.F., 2006. Sequential stagnation of Kamb ice stream, West Antarctica. Geophys. Res. Lett. 33 (14), 1-4.

Joughin, I., Bamber, J.L., Scambos, T., Tulaczyk, S., Fahnestock, M., MacAyeal, D.R. 2006. Integrating satellite observations with modelling: basal shear stress of the Filcher-Ronne ice streams, Antarctica. Philos. Trans. R. Soc. London 364 (1844), 1795-1814.

Morlighem, M., Seroussi, H., Larour, E., Rignot, E., 2013. Inversion of basal friction in Antarctica using exact and incomplete adjoints of a higher-order model. J. Geophys. Res. 118 (3), 1746-1753.

Pollard, D., DeConto, R.M., 2012. A simple inverse method for the distribution of basal sliding coefficients under ice sheets, applied to Antarctica. Cryosphere 6 (5), 953-971.

Retzlaff, R., Bentley, C.R., 1993. Timing of stagnation of ice stream C, West Antarctica, from short-pulse radar studies of buried surface crevasses. J. Glaciol. 39 (133) $553-561$. 